\title{
Coordination of Actors, Farmers - Processors and the Social Welfare of the Citizens in Peja
}

Sylë Kolica

The European University of Tirana, Faculty of Economics, profile - Management.

\begin{abstract}
Kosovo society is considered as strong consumer society with the need for liberalization of the labor market, active participation in the process of globalization and the promotion of "knowledge economy". Coordination of actors through associations and other forms of temporary association are prerequisite for enterprises, especially agribusiness related strategies growth and sustainability and being pro-business constitutes an essential condition to be pro-social, aware of the necessity of reconciliation policies free social market. Social Responsibility of enterprises, especially agribusiness Peja defined as a strong consumer, labor market liberalization and active participation of these enterprises with coordination of stakeholders in the process of globalization and the promotion of "knowledge economy". Peja agribusiness enterprises nowadays qualified as a period of liberalization are the first steps to understanding their fair economy intends putting it at the service of people considering the effectiveness of the market and minimal state. So in this case the state local government should create enabling environment for free breathing of these companies which are the only option for the social welfare of the citizens of the municipality of Peja and poverty reduction. The organization and coordination of stakeholders, farmers - among others profit maker also has another important instrument is therefore an instrument of social development under (JMKEYNES) Laissez faire works in these enterprises on the basis of the law of supply and demand, which itself regulates economic life of the citizens of Pec. Specification and focus on specific language variables gives discussed and explained the problem. Search theoretical judged and evaluated as the product of a cultural and institutional dispute.
\end{abstract}

Keywords: Social welfare, growth and sustainability, coordination of stakeholders, the knowledge economy.

1PHD (C) Sylë Kolica. Email: S. kolica@hotmail.com

\section{Introduction}

Our country therefore Peja municipality is relatively poor economies in the region and therefore problematic exit from this situation will affect the growth of social welfare of the municipality. Theory that without production there is no economic development pushed us to think seriously that the municipal government should create an enabling environment to create conditions for the manufacturing enterprise to grow and be sustainable to find new markets as meet the needs own to consumption. Food costs are a heavy burden for the population of the municipality, therefore, imports of these products should be reduced and replaced with local produce. Such a step, especially after the war have followed the best known companies in Peja such as Devolli company, ELKOS group, Bibita, Vokshi commerce, heels, Dardania, and brewery after changing his head. There are signs of increasing employment and household income from these manufacturing enterprises in Peja. Collection of raw materials such as milk, wheat and other agricultural products and meat have enabled unless the number of active workers outside employment. Peja municipality is characterized by the convenient geographical position which enables it to have an own raw materials for the food industry development. This industry Peja has existed since the early 70 s, before the war means an industrial zone southeast of the town of Pec at an altitude of 432 meters, near Kosovo Polje railway node - Peja and Peja highway - Pristina. Therefore justly can say that the geographical configuration of the municipality of Peja is in favor of the development of manufacturing enterprises that directly affect economic growth and social welfare of the citizens of Peja. Watching the historical development of manufacturing enterprises in the municipality of Peja and comparing these companies with those in the region that has seen a big difference in the dispute history- limit. 
This interval can not be discussed for years but for decades and centuries. Since the establishment of the industrial zone in Peja dates from the 70th starting with the brewery in Pec which was initially helped by the same factory in Germany. Like other municipalities, as well as the municipality of Peja bothering to challenge the high unemployment, so after war in Kosovo, some businessmen are beginning to realize that the economies of small family should be given priority for development to solve the problem of unemployment and increase revenue family, all this to achieve above average earnings and create social welfare. After the war the previous manufacturing enterprises except the brewery which immediately commence economic activity, others were destroyed and the privatization process for old technologies because they changed destination. Enterprises production in this municipality still bear the burden of the initial investment and the same have not yet reached the stage economic growth and social prosperity flow from these enterprises.

It said because the large number of employees is trading companies that import goods from the region most of which can be produced in our municipality. Therefore economic growth of the municipality of Pec and its social welfare as a whole can not be imagined without production as it is in the region and beyond. The mentality of the management of these enterprises is directed at agriculture as a source of raw materials for their products strategically such as milk Vita, flour and meat products in general Responsibility social and employment secondary from the manufacturing enterprise are explained in terms of the relations of these enterprises with stakeholders - farmer. (Milk collection points in the first case, and grain collection points in the second. ). This is the tendency of these enterprise that imported food products are replaced with domestic products because this region has favorable conditions for the industry grow which the municipality has particular industrial area.

\section{1. The purpose of the survey}

Peja Municipality is a territory with natural riches. At last period natural resources played an important role in economic and social development of the municipality. But all quality indicators show that the natural resources in the past in Peja were not enough factors of economic development and that these factors may in the future be many more factors that can influence the creation, growth and sustainability in production. The importance enterprises increasingly large domestic raw materials in the region with their lack facing humankind today directs the business world to be oriented development policy of the municipality. The last period of development was under heavy influence of economic structure in which political factors were implicated economic. sublimation discriminatory policy that natural resources in Peja can be important factors in development than the previous period is subject study very knowledgeable of macro-economic policies in the country. This will determine the volume and structure of natural resources and the possibility of their conservation and the impact of this structure on the economic development of the municipality of Pec. More this will also raise the issues of finding the ways to identify phenomena and obstacles in enterprises manufacturing in Peja. Taking into account these results in our paper will set forth the basic strategy of manufacturing enterprises in the municipality of Pec.

\section{2 The object of research}

The object of our research are manufacturing enterprises according to their structure and method of determining the mission of the strategy, growth and sustainability as well as production companies and environmental assessment of the internal and external of these enterprises at the same time the role of manufacturing enterprises in Peja for economic growth and citizens' social responsibility liberalization period and the state philosophy of "Laissez-Faire" which means that the economy should have no other purpose except profit and service to the people. (JM Keynes). Objective of paper in case concrete the ability of these enterprises to eliminate the problems that create additional costs and less competitive in other countries. Motive incentive for companies' farmers and agribusiness industry is a solid base in order to improve the trade balance of Kosovo because Peja has the resources and raw materials for industry. This would save the import of agricultural raw materials deposited more money abroad. During 2014 imports of these products have been spent over 800 million euros of which products can be produced in Peja, Kosovo. Research in the field of agribusiness enterprises in Peja supported in the medium and long term project during the design of the directorate for economic development municipality Peja.. Structure production in the municipality percentage skewed toward large agribusiness for geographical and climatic conditions allow it. During the survey and interviews on the ground in enterprises agribusiness in Peja has resulted styles of management in these enterprises represent a trend not very dynamic with a management style generally informal, not sufficiently focused on the qualification of people, lack of fit in their business environment which is very dynamic. Lack of projects and obtaining the same information for enterprises in the region and not well structure organization. government 
capacity professional and lack of investment in qualified quad pose difficulties during our research in these companies. Subsidies from the central government and local governments in recent years although still small interest added more farmer for higher productivity in these industries municipality. But as is meat, flour, milk and beer are doing research debates and development strategies of these enterprises. Economic Institute Rinvest has studied the main obstacles faced by these investors and they start by supplying improper power electric, legal and inadequate and inefficient, with is corruption high, political stability, market limited the north of Kosovo RESOLUTION 12/44 security council.

\section{3 The hypothesis of the paper.}

hypothesis. 1

The good management of the value chain through coordination of stakeholders and reduces the cost increases the strength of manufacturing enterprises in the municipality of Pec.

hypothesis. 2

Manufacturing enterprises have a single purpose which is above the average profit but also an instrument of social service.

\section{4 research Questions}

- How are capable manufacturing enterprises in Peja understand their competitors' goals and customer requirements.

- Is there a strategy for social responsibility by manufacturing in Peja.

\section{5 Research Methods}

The method is mainly quantitative analysis but we made every effort to correct the data used qualitative interviews with managers of manufacturing enterprises that are semi-structured and quantitative data were collected through questionnaires and plans of these companies. Mainly used in analysis is deduction, so going there and not have special access microeconomic analysis.

\section{6 The importance of the paper}

The paper is a case study of long duration and its importance lies in the fact that Peja emerged from the war completely destroyed feels great need to increase the production companies which enhance the level of economic and social welfare of the citizens of Peja. This matter consists in fact of importance to reduce the trade deficit and increasing interest in foreign direct investment. Since the early 70s a large number of citizens of Peja migrate westward therefore Kosovo society known as Friends of saving and mobilizing saving migration plays a role in the creation and sustainability of manufacturing enterprises and production entirely in the municipality of Pec.

\section{7 The problems observed}

Problems noted during interviews with the managers of these enterprises are lack of internal organization functional and understanding towards the evaluation premises of their business and initiatives of strategic enterprises that their operations with efficient and effectively to create a more responsive customer environment.

Chapter: II Management objectives and coordination of stakeholders in productive enterprises in the municipality of Pec.

Debate 2. 1 academic research on the development strategy of manufacturing enterprises in the municipality of Pec.

Schools which work is based on the German historical school because economic phenomena of these companies evaluated and judged as products of a historical cultural and institutional dispute. 
RIINVEST Institute in 2012 has given the main obstacles that affect foreign direct investment in manufacturing enterprises in general.

Today in the modern world more help the organization of their employees set goals to try to achieve the same thing organzation is in our country and production enterprises in our community so this is the process of management by objectives where supervisors and their dependents together define specific objectives of performance, periodically review the progress towards objectives and award prizes based on this progress in country uses to control objectives goals uses them to motivate why management by objectives in our community in these enterprises in the region as it is a system in which specific performance objectives determined jointly by their subordinates and supervisors where progress towards these objectives is reviewed periodically and where the rewards are assigned based on the latest progress bonuses decided phrases assigned based on the progress observed is highlighted more in the region and the need to make more room in these enterprises development. Management objectives in the enterprise turns into operational objectives thing taken by a process in which they all come down to what the organization it means that the overall enterprise objectives are translated into specific targets for each subsequent level in the organization, division, department and individual. Management objectives in these enterprise functions from the top down and vice versa from the top down. For employees of these enterprises represent these targets specific performance personal. So, every person has an identified specific contribution to give the performance of his unit what it means to all individuals in our manufacturing enterprises if they attain their goals and objectives then the unit will achieved. therefore those enterprises will be presented in a pyramid scheme called the manufacturing enterprise objectives. This scheme has its own objectives ranging from lying on individual, sector and department, you all when accessed circle objectives of the company, which is intentionally at all levels of managers in these companies as well as enterprises in the same region. According to the objectives of the manufacturing enterprises in the municipality of Peja pattern in the region will become a reality. All this by meeting these objectives at all levels and also by improving the requirements concise achievements expected. evaluation effectiveness in managing complex tasks objectives in these manufacturing companies, but about the management of these objectives, goals should set as a priority goal so sometimes resulting difficulty with these management issues specific to this performance effectively enhance the productivity of enterprises so high. Employers productivity of these enterprises have a clear idea and try to reach it while executives generally these companies have to check that this task is being fulfilled a helping employees to achieve their goals and objectives work. placement is a skill that every productive enterprise managers in Peja region as you try to reach therefore to achieve this process should be upholding some guidelines:

- Identify the job, then good source for this is the job description for each employee.

- Establish specific goals and adhesives for each of the main tasks this means that the specified goals for each employee by reducing confusion.

- Employees are made and are an integral part of these goals, which means that the employees in these companies understand that their work in manufacturing input is required.

- These companies have set goals that advantage that means lie within the setting of priorities, it is natural that these employees in our companies know that if these objectives are achieved what awards will be given to them. That happens in the region while not much practiced in our manufacturing enterprises.

Goals in these companies can be expected to be short term goals and long term goals, they have the character of generalized but within these enterprises are specified and rightly these are specific objectives that may include sales, market share quality of product and social responsibility. of our manufacturing enterprises in Peja usually find these specifications Vita expression enterprise manufacturing plans and puts itself the task than can be provided by milk farmers in the municipality and outside her. She organizes this transfer and transport of raw materials all over the territory the Dukagjini and beyond. Given the market conditions which is imperative and objective study of the management of this enterprise, then what amount required in the market that covers this enterprise it also plans additional raw material imports which is in the form of milk dust in countries in the region this material usually subsidized by the state because it is vital item. This enterprise absorbing this amount of raw materials from other farmers and pastoralists in Peja individual mitigate unemployment and indirectly affects the economic development of the municipality of raw our. planning in Peja Brewery is very different today after privatization this manufacturing enterprise with the period before the war and before the first 
privatization. Land pre-war period is provided by domestic production from fields Kosovo. Usually so in this period then until 1990 was almost planned economy and control industry by knowing the possibility manufacturing her. In this period payments were merely raw barley primary emission from broadcasting and the enterprise find its interest in two directions:

- Was cumulative barley agricultural production

- There was the possibility of using interest loans with affordable collection.

This manufacturing company had a contract with agricultural cooperatives to plant plots to the needs of the enterprise with barley. by knowing that these small cooperatives have the financial capability, beer factory undertook these steps:

\section{- Supply fare of barley \\ - Supply with fuel for planting \\ - The supply of fertilizers}

Because of the payment options that had this company when it become the barley harvest had already paid half the value of her. inflation enable financial benefit from the show also used primary credit with minimal interest to collect barley, during the 1980s - 1990 existed as a means of guaranteeing the banks' payment of these were bills that created the possibility that debts be paid within 90 days. After 1990 Yugoslav state of war where every day gripped printed without cover and financial resources every week from the existing banknotes atone for some zero domination especially the case at the time of Avramovic (Serbian economist and businessman who has lived in the US). In this whole time what the market produced and sold on the day after losing $50 \%$ of value within the enterprise real. In and co with him was organized as agricultural industrial combine with other companies was besides sugar factory was that of malt which no longer works today. In the context of this combine was the social enterprise itself Agriculture which had large tracts of land which after the war as a whole is private In the area this enterprise also cultivated barley as raw material for the production of beer and the same process the factory of malt in the framework of this combine. From this day remain privatized brewery which malt as raw material for beer production provides mainly imported mainly from Rusia. Planning for this raw material adheres to sustainability objectives but rather grow. From financial statements of manufacturing enterprises after privatization this shows that the costs of raw materials for 2007 were 2. 232. 982. $21 €$ while in the last year of the course costs therefore are 3. 199. 701. $37 €$ malt because we have increased productivity and greater sales compared with the previous year until 2007 revenues from beer sales were $€ 20,952,700$ to $€ 23,632,183$ in 2012. From it appears that the manufacturing enterprise brewery is set for mission to find new markets abroad country means countries in the region, increased sales and greater need for planning the object of first. From costs of raw materials ranging from 2005 to 2012 have shown that the process of growth and sustainability as targets contemporary. From its management specifics of some other companies manufacturing in this municipality as a raw material for water and land can be mentioned in Radavc hydropower Radavci who uses the White Drin water to produce electricity with a capacity of 2 megawatt. quantity water as fuel for power generation is not electric same period during the year. It differs in seasons where there is more rainfall and capacity is the largest production such as spring and autumn and during the summer a thing does not happen because it keeps the heat from the source water uses and brewery and water supply networks in many places in this municipality. Planning of electricity in hydropower is difficult because it depends on climate factors that will mean varies from year to year. enterprises for production of construction material as stiff clay now called after the privatization Ringovi new uses as raw material in the surface soil that surrounds this enterprise manufacturing. capacity manufacturer of this enterprise is conditioned by supply and demand in the market because in Kosovo and in the region there are many types of companies and this kind of technology in these companies do not correspond to standards identical enterprises in the new region. Factory dough using flour as the raw materials produced in our manufacturing enterprises in Kosovo, the majority of mill Zerzes planning this course suits also the first product supply and demand of this subject in market. Factors that affect the management of raw materials in the manufacturing enterprise are mainly external factors that depend on imported raw materials, these external factors are:

- Market not controlled enough (free market laws are violated) 
- Customs Inefficiency

- Good fiscal policy and not the state actions for the preservation of local products

- Unfair competition

- Quality issues and market prices

For most of these manufacturing enterprises in the municipality of Peja brewery that are fluid milk Bibita styroprit Vita, Ukaj company, production of flour Dardania, enterprise taka, Gacaferi, the plan mainly supply raw materials from import. Has market opportunities due to non-controlled and the northern part of the country where there is no customs control at the institutional protection - here there is a possibility of a market not control. Politic not good for the VAT tax for raw materials paid in advance before enter the production process compared with companies in the region there after the VAT paid on raw materials entering the production process and he realized production. This Republic difficult manufacturers in our community and beyond in Kosovo at the same time prevents direct investments and those common in private equity. These are usually external factors that influence the development of manufacturing enterprises in the municipality of Pec but you have to Kosovo. owing to opportunities for production of raw materials, territory and the small distance to the market have the opportunity of forming more affordable prices by our competitors, this advantage competitive if it is planned that the raw material in many products our companies to be from the Kosovo market because of transport costs on imports that make now the manufacturing enterprise will have priority in relation to competitors from 10 to $15 \%$ cheaper. Therefore, the government of Kosovo to the way the food industry to be more competitive should think that the share of investments from budget Kosovo for agricultural sector which provides incentives to our farmers to increase the number of cattle and farmers inseminated culture wheat as raw the first plants for the production of flour and bread, and provision of legal and procedural incentives for foreign investors to direct investment to invest in capacity building for manufacturing malt from barley, which will be cultivated on land which the Kosovo. production made in the former combine wood now Kosovo EOOD Peja often largely exported abroad planning and provision of raw materials for this product is made by import and other enterprises trading in Kosovo that should pay taxes at customs VAT 16\% and repayment export is carried out lengthy and complicated it is best to speak with inadequate fiscal policy for the development of these manufacturing enterprises in Peja such a thing goes for lactation in Vita production company in the dairy Pec. Buying raw material from farmers in villages farmer and does not allow the collection of value added tax and the final product from raw material imposes $16 \%$ tax on the value added that makes not much time competitor in our market inside municipality characterized by a large number of small businesses that deal with the production of bread and bakery dough etc. Those are that raw material mainly supplied flour from local producers such as Dardania in Peja. Therefore, in this region the only serious subject is the industry of flour which processing with capacities of 70 tons of wheat is about 24 hours. Planning of raw materials for manufacturing industries analysis done by soil structure that is in the municipality. near $50 \%$ of the territory of the region of Dukagjin used for crop production shows that when it comes to large amounts of wheat, rye and maize evaluation is over 25,000 tons year. those company has over 3000 farmer that collaborate in field grain from all regions of Dukagjin, not only cereals but also in spring and autumn farmers provides artificial fertilizers and quality seed for cereal with opportunities compensation their natural products that have been submitted. Farmers can all work or service at any time to sell their crops in this industry flour. Is particularly important that there is excellent cooperation and Cooperation with Serbian and Bosnian community. To plan this raw material industry has made development cooperation at the production of wheat and corn by creating its own collection points in all regions of Dukagjin. Collection points where farmers intended center of that region submit a flour cereals industry "Dardania" and where receive free packaging and take flour, SEK, concentrate, and in the period of sowing seeds and fertilizers take artificial. Point is open all year round and all collectors are paid by quantity. Industry flour $\%$ Dardania planning the first case that made based on existing collection points such as:

Municipality of Peja 2000 ha

\section{The municipality of Decani 502 ha}

2. The municipality of Istok 2838 ha

3. The municipality of Klina 3044 ha 
Total 8584 ha, these data are for parcels over 2 ha, while for parcels smaller than 2 ha no data due to limits that I have given Kosovo's government subsidy.

Calculated that wheat planted in parcels smaller than 2 hectares has around $35 \%$ it appears that 8584 ha $\times 35 \%$ yield which 3004 ha are outside evidence. It follows that in this region has planted over 11588 ha and if the average yield 3.5 tons per ha then waited harvests this industry 40558. Pra flour raw material planning wheat made based on information from municipal assemblies - director of Agriculture in these municipalities taking evidence on planting this crop. As a staple of this enterprise which exploits for producing maize flour to feed people, cattle meal planned for the staple maize which is used for industrial processing of flour for enterprise. Industry Dardania in Peja line for maize processing, a technology developed by Switzerland which can produce 40 tones of maize per day coordination actor means of cost reduction and the concept is known in the literature as good management of the value chain. For the good management of the value chain and customer relationship to affect the growth and sustainability of manufacturing enterprises in Peja (hypothesis 1) of the paper. Lately by these Managers of these enterprises have begun the first signs that these enterprises can enhance their export capabilities that little bit To enhance trade deficit that has Chuang probably the largest in 40 years. This is a well thought out policy of central and local government, through subsidies and recent law fiscal policy. Implementation of the research plan is extended in time and space in which enterprises are the result of the privatization of the post-war period and others that have launched in the 90's years as family businesses that have expanded postwar activity. Example company "Devoll" (production of milk and its products, the company "Elkos" group (processing of meat and fruits and vegetables and flour industry "Dardania" in Peja.

\section{2 Social responsibility as a strategy of manufacturing enterprises in the municipality of Pec.}

J. M. Keynes 60 years after his death that the economy remained in force should have the primary purpose of putting her to serve the people, but in our context not exasperate market and the effectiveness of the state. From the analysis of manufacturing enterprises in the municipality of Peja taking into account statistics and accounting records of these companies see a significant increase in the nominal strength of the labor force. Important role worth mentioning is the company Devolli with milk collection through multiple points of farmers in Peja and wide and flour industry Dardania also collection points wheat not only in terms of Dukagjin but in part Kosovo large group and ELKOS company in the collection of agricultural products which are stored in refrigerator with large capacity and meat that has stimulated the development of livestock in the Pec region and beyond. These reflections are positive signs in employment secondary population of the municipality of Pec.

Interpretation of the data analysis:

Autumn crops by municipalities where the wheat covered by IM "Dardania. "

\begin{tabular}{|l|l|l|}
\hline $\begin{array}{l}\text { Crops planned and Execution } \\
\text { Municipality of Peja }\end{array}$ & Surface realized & Number of farmer \\
\hline Municipality of Deçan & $\mathrm{Ha}$ & 650 \\
\hline Municipality of Istok & $\mathrm{Ha}$ & 400 \\
\hline Municipality of Klina & $\mathrm{ha}$ & 1100 \\
\hline 5. Total & $\mathrm{ha}$ & 2760 \\
\hline $\begin{array}{l}\text { Plots on }<2 \mathrm{ha}=35 \% \text { of total } \\
\text { planting that }=3004 \text { ha. }\end{array}$ & & 3004 \\
\hline 7. Total planting & $11588 \mathrm{ha}^{*} 3.5 \mathrm{t} / \mathrm{ha}=40558 \mathrm{t}$ & 5764 \\
\hline $\begin{array}{l}40558 t^{*} 56 \%=22713 t \text { flour and } \\
40558 * 29 \%=11762 t \text { animal food }\end{array}$ & & 5764 \\
\hline \begin{tabular}{l} 
Annual production capacity \\
\hline
\end{tabular} & $27458 t-22713=4745$ & 5764 \\
\hline
\end{tabular}




\begin{tabular}{|l|l|l|}
\hline Imports of raw wheat by capacity & $4745 t$ & 5764 \\
\hline $\begin{array}{l}\text { Percentage of domestic grain raw } \\
\text { materials }\end{array}$ & $79 \%$ & 5764 \\
\hline
\end{tabular}

From the data of the raw material planning in IM "Dardania" it shows that $79 \%$ of the raw material provided by the market of the country, while $21.1 \%$ is imported raw materials. Comparing 2014 with 2006 has increased by 300 farmer as they were in 2006 to 3205 in 2014 the upward trend. The trend growth plan Dardania flour industry is the expansion of collection points in the Drenica region and Anamorava and plans to increase the number of farmer $300 \mathrm{IM}$ also produces dietary fiber from corn flour which until

\begin{tabular}{|l|l|l|l|l|l|}
\hline Municipality & $\begin{array}{l}\text { Month base } \\
\text { Liter }\end{array}$ & Price & Month value & Month & Year \\
\hline Peja & 25470 & 0.35 & 8915 & 12 & 106974 \\
\hline Klina & 24850 & 0.35 & 8698 & 12 & 104370 \\
\hline Istok & 23840 & 0.35 & 8344 & 12 & 100128 \\
\hline Total & 52700 & 0.35 & 51153 & 12 & 613836 \\
\hline
\end{tabular}

$201490 \%$ of raw materials mainly imported from Serbia. While feed product is a result of the flour originates in percentage 79. $1 \%$. From the scheme of supply of raw milk from farmers in the municipality of Pec, Klina and Istok that means from Peja region shows that provide raw materials advances in Peja it easy to Klina and Istok.

SOURCE: dairy supply scheme VITA Peja.

Liters monthly basis.

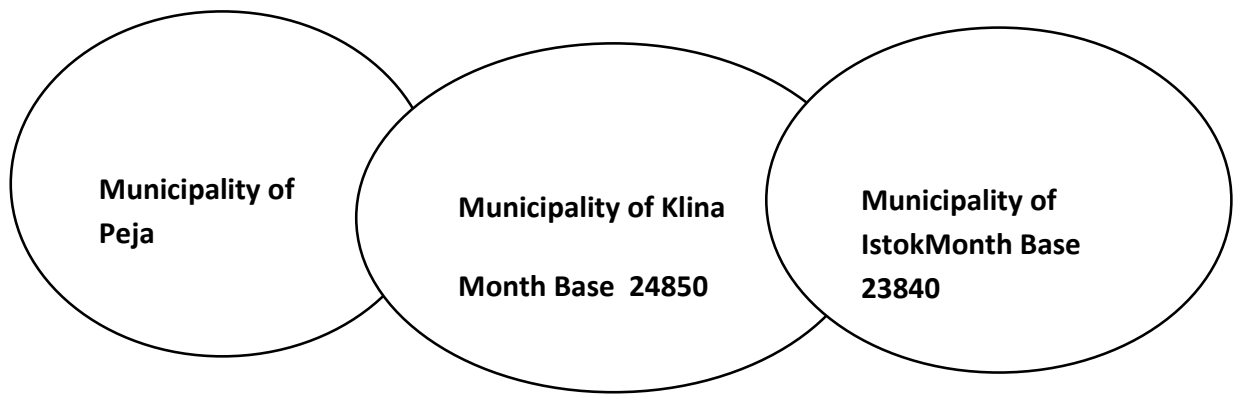

The table shows that the company has increased the social welfare of the citizens of the three municipalities for 613836 euros, while the capacity of the company produced 52700 liters of milk product turns out that only $29 \%$ of this product supplied from domestic market with raw materials

first and $71 \%$ from imports as milk powder. This is due to lack of subsidy from the government and problems of VAT on purchases. 


\section{Chapter III: Empirical analysis of the paper.}

\section{1 Results}

Table 1: Correlation between good-value chain management and sustainability of the growth of manufacturing enterprises in the municipality of Pec.

correlations

Good management of the value chain of the enterprise growth and resistivity

Good management of the value chain Pearson Correlation 1.251 *

Sig. (2-tailed). 041

\section{N 6767}

Growth enterprises and resistivity of Pearson Correlation. 251 * 1

Sig. (2-tailed). 041

\section{N 6767}

*. Correlation is significant at the 0:05 level (2-tailed).

To test the first hypothesis of this study: "Good management value chain and good relations with customers affect effectively in the growth and sustainability of manufacturing enterprises in the municipality of Pec. "Became correlation analysis and we have the result [ ${ }^{*} r=.251$ and $\left.p<.041\right]$.

So connectivity is reported the first confirmed hypothesis

Results are derived from questionnaires that were made in 67 companies manufacturing in Peja in total 30 questions closed.

\section{Chapter IV : Conclusions, Recommendations}

Unable to modern manufacturing technology to our country, and the lack of foreign investors for these products required to loosen fiscal policy from customs and VAT payments of all importers of the technology for production. Lack of capital in these enterprises favors the import of used machinery half. Liberalization of import of such machinery is welcome because it is cheaper and is insufficient for this initial phase of adjustment production activities in our community. We must harness the new age of the population and the need for new job-educated generation that promise qualitative use of this quality.

In these enterprises is indispensable investment in the education of new generations in the form of scholarships and student loans for branches and profiles that are necessary for the manufacturing enterprise. Technological advancement be given priority in order to reduce the cost of production which enables higher productivity and greater export in order to improve from Kosovo's trade balance is in general. In our reality we should give priority to the small economy mainly Peja has ideal conditions for agribusiness that its products will meet the market needs of Kosovo.

This will have an effect on experience and culture adjustment production of this municipality, reducing unemployment and poverty reduction. Eliminate formal barriers which are harmful to the environment of these enterprises. Should the legal infrastructure to perform its function, to pay taxes to Kosovo budget and be outside the spirit of daily politics. Fighting negative phenomena in local governance such as corruption, violence, informality and smuggling is a legal obligation of the executive. All these phenomena affect adversely the development of these productive enterprises, so elimination of 
these negative phenomena is oxygen to breathe better these manufacturing enterprises which are the hope of the citizens of the Municipality of Peja for economic growth and social welfare of our municipality. Department for agriculture, forestry and hydro economy is in conjunction with the ministry of agriculture and to apply for grants and subsidies for farmers and ranchers of the municipality who can enhance their products, the production capacities of existing enterprises. Environment of these enterprises in the municipality of Peja and the geographical position of the municipality, the fertile land, water of high quality and favorable climate characterize the environment of the municipality with the possibility of the development of food industry in ways that imported food products be replaced by local ones.

\section{Bibliography}

[1] Wealth of Nations Adam Smith, Tirana Day, 2000, 2005

[2] Operations Management: concepts, methods, strategies Panariti Suzana.

[3] Tirana: Adel 2008 Bot. 3rd.

[4] Microeconomic Analysis (3-d Edition), Hal R. Varian. Norton \& Company - New York - London; 2008.

[5] Fundamentals of Management, Robbin \& DeCenco 2010, UET Press.

[6] International Business, I. Kristo, University Publishing House, Tirana.

[7] Dilemmas of Development: models of economic development and social face of globalization.

[8] Adrian Civici Tirana: Geer 2007.

[9] Economics Paul A. Samuelson; William D. Nordhaus, Boston: McGraw-Hill Book Co.

[10] D. D. E. Strategy for the development of the municipality of Peja, 2013/2017.

[11] Design and analysis of the first case in IM "Dardania" in 2014.

[12] Plan of raw material analysis in Devolli company, 2014.

[13] Sources from the Internet.

[14] www. devolli. com

[15] www. dardania. com

[16] www. bibita. com

[17] www. birrapeja. com

[18] www. elkoscenter. com 